\title{
Turbulences associated with the implementation of turnaround strategies at Kenya Airways
}

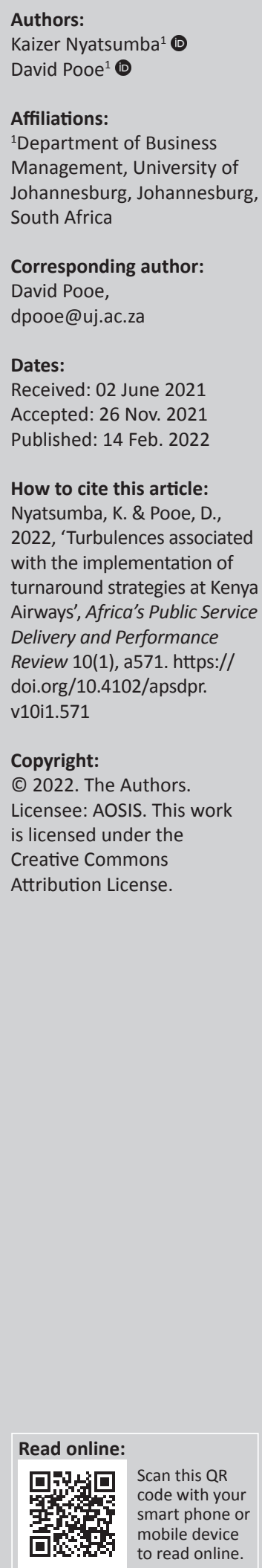

Background: At its formation, Kenya Airways (KQ) was poorly capitalised and its management team highly inexperienced. The airline's financial and related performance deteriorated from the early years, thus affecting the airline's financial health and its reputation negatively. In an effort to correct matters, KQ went through four turnaround situations over the years.

Aim: This article explores experiences and challenges associated with the KQ implementation of its turnaround strategies.

Setting: The study is based on KQ, which has seen one turnaround between 2004 and 2016.

Method: The article adopted a qualitative research approach using a case study research design. Eleven participants were purposively selected for the interviews. Documents were also used as sources of data. Thematic data analysis was used as a form of content analysis.

Results: Seven themes emerged from the primary data analysis. These include: employee involvement, exogenous factors, high operational and debt servicing costs, managementunion conflict, debt restructuring, nationalisation and leadership.

Conclusion: The study concludes that the kind of leadership required during turnaround situations differs from when the company is on autopilot. During turnaround times, the chief executive officer (CEO) needs to exercise the authority recommended in the literature and that the shareholder and the board needs to give them the necessary space to exercise such authority.

Keywords: Kenya Airlines; turnaround strategy; aviation industry; leadership; employee involvement.

\section{Introduction and background}

The airline industry is amongst the most competitive, highly regulated and capital-intensive industries in the world (Heshmati \& Kim 2016; Wolla \& Backus 2018). External factors, such as natural disasters, health emergencies and socio-political developments, all have the potential to disrupt the airline industry and its financial health (Jin, Qu \& Bao 2019; Rossello, Becken \& Santana Gallego 2020). In addition to being intensely competitive, the industry is also labour intensive and faces numerous structural challenges, which include: fluctuating fuel cost, airport charges, rigid labour laws and a higher cost of capital, amongst others (Chattopadhyay 2015; Doganis 2019). Whilst the industry has weathered many storms over the years and survived, the fast paced environmental and technological changes have increased the chance of a company's strategy being ill-matched to the changing environment (Pretorius 2009; Reeves, Haanaes \& Sinha 2015).

As the airlines were faced with and experienced various challenges, they have found it necessary to implement some urgent interventions with a view to turning themselves around (Reeves et al. 2015; Trahms, Ndofor \& Sirmon 2013). Bibeault (1999) calls the business state that requires a decisive management intervention turnaround situation. He described a turnaround situation as 'an abnormal period in any company's history' (Bibeault 1999:1) which requires unique management approaches that are vastly different from those used during a normal period. During such a period, proven management principles routinely used during times of stability are no longer valid (Bibeault 1999; Trahms et al. 2013:1278). Yet, not all efforts aimed at implementing turnaround strategies yield desired results (Ghazzawi 2018). According to Bibeault (1999), most turnaround failures are because of ineffective management, insufficient financial resources and a poor turnaround strategy.

At its formation, Kenya Airways (KQ) was poorly capitalised and its management team was highly inexperienced. The airline's financial and related performance deteriorated from the early years, thus affecting the its financial health and its reputation negatively (Debrah \& Toroitich 2005). In an 
effort to correct this situation, $\mathrm{KQ}$ went through four turnaround situations between 2004 and 2016. This article explores experiences and challenges associated with the implementation of turnaround strategies of KQ. Although much has been written on the subject of turnaround strategies and failures, ample remains unexplored (Ayiecha \& Katuse 2014; Trahms et al. 2013). Furthermore, investigating turnaround failures from a company based in East Africa will be a breath of fresh air in a research area dominated by knowledge and experiences based on American and European case studies.

A recent study on turnarounds at the Postal Corporation of Kenya (Mburu 2016) recommended more studies into the phenomenon of turnarounds, especially for Kenyan parastatal or state owned enterprises (SOEs). A more recent study in Kenya, which investigated some 144 firms linked to the Kenyan aviation industry, found that turnaround strategies had a major influence on the performance of firms in the aviation industry in Kenya (Nduta \& Deya 2020). Following their studies, Nduta and Deya (2020) recommended that more studies should be conducted to assess the challenges facing the implementation of turnaround strategies amongst the aviation firms in Kenya. Hence, this study explored the experiences and challenges associated with theimplementation of the turnaround strategies at $\mathrm{KQ}$.

The article is organised as follows: It starts by providing the background of a case under investigation followed by a review of the relevant literature. The article then proceeds to explain the research methodology employed followed by the research findings. It concludes with recommendations and avenues of future research.

\section{Background of the case}

Kenya Airways was formed following the liquidation in the same month of the East African Airways Corporation, which was jointly owned by the governments of Kenya, Uganda and Tanzania. Collectively, the three countries constituted the East African Community that was formed in 1967 as an economic union after they had each won their independence from the former colonial power, Britain. A governmentowned airline and Kenyan flag carrier, KQ was incorporated on 22 January 1977 (Debrah \& Toroitich 2005).

Following years of losses, KQ was privatised in January 1996 when Dutch Royal Airlines, KLM, bought a 26\% stake in the airline, and in June that year, it was listed on the Nairobi Stock Exchange. The Kenyan government raised US\$70 million through the sale of its shares and retained a $22 \%$ shareholding in KQ; employees benefitted from an Employee Share Ownership Plan and 113000 private East African shareholders bought shares in the airline. It was the largest share issue in Kenya at that time, amounting to $6 \%$ of the total market capitalisation (Debrah \& Toroitich 2005).

The privatisation of KQ was not solely an economic decision. Instead, external politico-economic pressure played an important role. Around the time of the privatisation of the airline, the heavily indebted Kenyan government was under immense pressure from donors to embark on structural adjustment programmes which culminated in the privatisation of not only KQ, but also Mumias Sugar Company and Uchumi Supermarkets (Munaita 2015), amongst others, with the help of the World Bank's International Finance Corporation. Since then, the main milestones in the airline's history have been as follows.

Whilst KQ became remarkably profitable following its privatisation, its profits started waning gradually from 2000. In 2004, the then chief executive officer (CEO) Titus Naikuni, who was the first Kenyan to run the airline when he was appointed in February 2003 replacing Briton Brian Prestbury (Brinson 2002), launched the airline's first post-privatisation turnaround strategy, which was called the Kenya Airways Turnaround Plan (KATAP). The strategy focused on revenue generation and cost containment and solicited suggestions from employees. The KATAP led to 800 employees being retrenched and was deemed a great success. In 2011, a year after Ethiopian Airlines (EAL) had launched its ambitious growth strategy called Vision 2025, which included aggressive route expansion and fleet acquisition, $\mathrm{KQ}$ launched its own growth strategy called Project Mawingu. The Vision 2025 of EAL followed the phenomenal success of its Vision 2010, which was launched in 2005 (Oqubay \& Tesfachew 2019).

In KiSwahili (Swahili), 'mawingu' means 'clouds', a word which aptly captures KQ's ambition to conquer the African clouds (Amollo 2015; Munaita 2015; Thiong'o 2012). Through Project Mawingu, KQ aimed 'to connect Africa through Nairobi to North America (USA and Canada), South America and Australia' and to launch seven new routes into China, six in the Indian sub-continent and three across North and Southeast Asia (Amollo 2015). Project Mawingu was about increasing the size of the KQ fleet from 42 aircrafts to 115 by 2021 and increasing the airline's destinations from 58 to 117 'in 77 countries in six continents' (Amollo 2015; Thion g'o 2015). With Jomo Kenyatta International Airport (JKIA) in Nairobi as a major African hub for flights from the East, KQ and its partner, KLM, were expected to 'pick up fares to the rest of Africa and Europe' (Munaita 2015). A high-level summary of KQ's 40-year history and milestones up to 2017 is captured in Table 1.

\section{Literature review}

Intense competition and environmental factors have impacted business in different ways. Whilst companies with ample resources which tend to be the first movers in technology adoption and which are more adept at responding to environmental challenges have grown phenomenally beyond their borders, others have struggled to cope and have needed deliberate management interventions to be able to survive (Suarez \& Lanzolla 2007). Panicker and Manimala (2015) described a corporate turnaround as 'a doubly entrepreneurial act' that has to lead a company 'from negative to breakeven and from breakeven to growth', with the strategies used to accomplish this goal being identical to 
TABLE 1: History and milestones of Kenya Airways.

\begin{tabular}{|c|c|}
\hline Years & Milestones \\
\hline 1977 & Establishment after break-up of the EAC \\
\hline 1994 & Commercialisation \\
\hline 1996 & Privatisation \\
\hline 2003 & Acquisition of $49 \%$ share in Precision Air \\
\hline 2004 & Delivery of first 777 aircrafts \\
\hline 2009 & ISAGO certification (21st in the world and first in Africa) \\
\hline 2010 & KQ granted full sky \\
\hline 2012 & $\begin{array}{l}\text { First airline in Africa to raise capital from investors across the globe } \\
\text { through the rights issue }\end{array}$ \\
\hline 2014 & $\begin{array}{l}\text { - KQ receives first Dreamliner B787-8 } \\
\text { - Westgate Mall attack of } 2013 \text { paralyses the tourism sector } \\
\text { - Outbreak of Ebola in West Africa }\end{array}$ \\
\hline 2015 & KQ posts record-breaking net-loss of KSh26.2 billion \\
\hline 2016 & $\begin{array}{l}\text { - Implementation of Operation Pride begins } \\
\text { - KQ begins sale of aircrafts }\end{array}$ \\
\hline 2017 & $\begin{array}{l}\text { - KQ marks } 40 \text { years in the skies } \\
\text { - Launches an unprecedented capital optimisation plan dubbed } \\
\text { Project Safari }\end{array}$ \\
\hline
\end{tabular}

Source: Kenya Airways, 2017, 40 Years of Pride. Annual Report \& Financial Statements, viewed 23 September 2020, from https://www.kenya-airways.com/uploadedFiles/Content/ About_Us/Investor_Information/Book\%20KQ\%2010996\%20Annual\%20Report_Website.pdf EAC, East African Airways Corporation; KQ, Kenya Airways; ISAGO, IATA's Safety Audit for Ground Operations.

those adopted by entrepreneurs. Often those interventions had taken the form of turnaround strategies, whose purpose was to arrest the decline and help those businesses to recover (Pretorius 2009; Reeves et al. 2015; Trahms et al. 2013). If left unattended, or if not attended to at the relevant time, a decline in a company's performance may ultimately lead to its failure and bankruptcy (Pretorius 2009).

The steps taken by a company to arrest and reverse the economic decline are called turnaround strategies, and the chosen activities to accomplish this goal are known as turnaround tactics (Gotteiner, Mas-Mashuca \& Marimon 2019). Following the implementation of a turnaround strategy, a company can only be considered to have been turned around when its performance before and after the decline has changed faster than the industry average. Ravaghi, Mannion and Sajadi (2017) added that understanding the causes of decline and the factors that can lead to success is crucial if effective strategies are to be designed to counter underperformance.

Developing such effective strategies to counter under performance calls for the top management team (TMT) and the board of directors (BoD) to understand why a company's performance declined in the first place (Kalwani 2012), to ensure that a turnaround strategy is implemented early enough and that it addresses the sources of decline (Ghazzawi, 2018). Arogyaswamy et al. (1995:506) warned that apart from potentially threatening a company's continued existence, corporate declines lead to a company losing the support of external stakeholders like shareholders, customers and financial institutions, becoming more inefficient internally and losing some of their valued employees. This makes it imperative to arrest and reverse a decline as soon as possible through an appropriate turnaround strategy (Ghazzawi 2018; Pretorius 2009).

In their review of turnaround literature spanning a 20-year period (1994-2013), Trahms et al. (2013) found that a company's strategic leadership - made up of the BoD, the CEO and the TMT - can either impede or facilitate implementation of a turnaround strategy. However, they concluded with the observation that more research still needs to be done into the relationship between a $\mathrm{BoD}$ and a company's TMT to establish its impact on a turnaround outcome. In their paper on 'turnaround leadership core tensions' during a company's turnaround process, O'Kane and Cunningham (2014) identified 'disposition' as one of the six important tensions worthy of close scrutiny. They used the construct to refer to the degree to which a company's TMT promotes 'urgency regarding the magnitude of the situation and convey[s] composure to evoke confidence'.

The replacement of a CEO and/or the TMT for political or symbolic reasons forms an important part of the vast majority of turnaround strategies. Such an action not only ascribes responsibility for the organisational decline, but also sends a strong message to various internal and external stakeholders that things have changed or are about to change (Walshe et al. 2010). Dimopoulos and Wagner (2016) concluded that replacing the CEO remains a vital ingredient for successful turnarounds in underperforming companies. Trahms et al. (2013) described managerial cognition as referring to what a company's leadership team considers to be the cause(s) of decline and the way it responds to the perceived cause(s). They say three cognitive factors affect a TMT's subsequent turnaround actions: its formal awareness of decline, the factors (whether internal or external) to which it attributes the decline and its perceptions of the severity of the decline. Parrick (2018) made the point that some of the most successful businesses have failed at some stage. She contended that if handled correctly, a company's decline could be the checked which can help it in climbing back to the top.

Trahms et al. (2013) observed that governance mechanisms might have a different influence on companies grappling with a decline when compared to those experiencing growth. In part, this study was a response to the challenges identified by Schoenberg, Collier and Bowman (2013) and Trahms et al. (2013), amongst others, but approached the implementation of turnaround strategies from an African perspective and sought to establish whether there are determinants which contribute towards or detract from the successful implementation of a turnaround strategy.

\section{Conceptual framework for the implementation of turnaround strategy}

In an effort to answer the research questions about the determinants of a successful turnaround strategy implementation, attention was paid to the roles of shareholder disposition, organisational stability and decision rights as constructs. In particular, a critical examination of how and why the aforementioned constructs contributed towards or detracted from the successful implementation of turnaround strategies was made. A construct is an abstraction that helps a researcher to understand the essence of what the phenomena are and how they operate (Carlile \& Christensen 2005), an 
image or abstract idea specifically created for a given research or theory-building purpose (Cooper \& Schindler 2014) and an abstraction, used for scientific purposes in building theories, formed by generalising from specific behaviours or manipulations (Rudestam \& Newton 2015).

'Organisational stability' was used in this study to refer to the degree to which stability is obtained within an organisation or company, especially at top leadership level. It refers to the frequency with which a company changes managing directors (MDs) or CEOs and the duration of such executives' tenure in office, especially during the development and implementation of a turnaround strategy. In this study, 'disposition' was used to refer, in particular, to the shareholder's approach, through the $\mathrm{BoD}$, to the CEO and the TMT through the kind of authority delegated to the CEO to manage a turnaround process. In particular, it refers to whether the shareholder in question involved himself, herself or itself directly in the running of the company, meddling with responsibilities that are ordinarily deemed to belong to the management team in terms of the South African Companies Act 71 of 2008, or whether he, she or it had a generally hands-off approach that entrusted the running of the company to an empowered management team accountable to a BoD. 'Decision rights' was used here to refer to the extent to which everybody within a company understood where and by whom certain decisions were to be made and where final accountability for those decisions lay (Neilson, Martin \& Powers 2011). In their extensive research into decision-making at global companies, Rogers and Blenko (2011) found that successful companies routinely tend to make high-quality decisions quickly and execute them effectively, with clarity obtained throughout the company about who is responsible for recommending decisions, approving the recommendations, making inputs, taking final decisions and implementing those decisions.

To guide and bound the research, three main theoretical propositions bases on the turnaround management literature were posited, namely:

- A supportive shareholder who leaves a capable, empowered management team to run a company under the direction of a similarly supportive BoD increases the chances of a company's success in implementing turnaround strategies;

- Organisational stability at top leadership level increases the chances of success in implementing turnaround strategies and

- Clarity on decision rights and accountability within an organisation increases the chances of success in implementing a company's turnaround strategies.

These three theoretical propositions, which are a vital part of the study's research design, were intended to guide and bound the research, including the data collection and analysis. They were important in placing tentative limits on the scope of the study and making it more feasible for the researcher to complete the research in the time available (Baxter \& Jack 2008:551).
TABLE 2: Profile of Kenya Airways interview participants.

\begin{tabular}{lc}
\hline Position & Identified as \\
\hline Former Chief Executive Officer & P1 \\
Former Strategy Director & P2 \\
Former IT Director & P3 \\
Former Marketing Director & P4 \\
Former Communications Manager & P5 \\
Shareholder representative & P6 \\
Aviation expert & P7 \\
Aviation journalist & P8 \\
Ethiopian aviation journalist & P9 \\
Kenyan aviation researcher & P10 \\
Kenyan Airways Relations Consultant & P11 \\
\hline
\end{tabular}

IT, information technology

\section{Research methodology Research approach}

A qualitative research methodology, using an interpretivist philosophy was adopted in this study. According to Marczyk, DeMatteo and Fesinger (2005), qualitative research is most appropriate for studies that typically involve interviews and observations, and not any form of measurement or a statistical summary. As the focus of this study was the $K Q$, the research design adopted in this study was a case study, defined by Yin (2014), as an empirical study that investigates a contemporary phenomenon in depth and within its real-world context, especially when it is not easy to distinguish the boundaries between the phenomenon and the context.

Purposive sampling was used to select participants to be interviewed for this study. Data were collected primarily through semi-structured interviews. Eleven interviews were conducted, five of whom were directly involved in Operation Pride and Project Safari and had recently left the airline, with three of them having been with $\mathrm{KQ}$ long enough to have recollections of the 2005 turnaround strategy. These respondents had sufficient in-depth knowledge and experience about the case that data saturation was reached after the 11th respondent (Hennink, Kaiser \& Marconi 2016; McMillan \& Schumacher 2010). Interviews afford the researcher the opportunity to allow respondents to expound on certain questions, thoughts, perspectives and feelings (Bryman \& Bell 2014). The interviews were transcribed. The profile of the interview participants is shown in Table 2.

In this study, the researcher was the main analyst and sought to work the data from the ground up. Plausible rival explanations were also examined. Specifically, the researcher went through each interview transcript painstakingly, physically making notes in the process and highlighting in different colours sections of the interview texts which dealt with identical themes. Broad thematic analysis, as advocated by Nowell et al. (2017) was used. During the data analysis, in instances where certain aspects were not clear or were contradicted by other participants during interviews, clarity was sought in writing from the relevant participants. Research ethics involving the principles and codes of conduct were observed in the process of gathering, analysing, interpreting and disseminating the results of the research (Bhattacherjee 2012). 
TABLE 3: A summary of themes from Kenya Airways data.

\begin{tabular}{ll}
\hline Theme number & Description \\
\hline 1 & Employee involvement \\
2 & Exogenous factors \\
3 & High operational and debt servicing costs \\
4 & Management-Union conflict \\
5 & Debt restructuring \\
6 & Nationalisation \\
7 & Leadership \\
\hline
\end{tabular}

\section{Research findings}

The primary data from the interviews led into the following themes.

\section{Theme 1: Employee involvement}

The involvement of employees in the search for solutions to KQ's challenges emerged as one of the main themes during primary data collection. A number of interview participants painted a picture of a consultative leadership team, which used town-hall meetings to describe the enormity of the challenges facing the airline and invited employees to suggest ways in which more revenue could be generated and costs contained. This practice started in 2004 when the KATAP was launched.

\section{One respondent described the then CEO as:}

'A charismatic man who had exceptional communication skills, had the ability to define a problem and "break it down into very simple messages that everybody - even on the shop-floor - can be able to understand."' (P3, Former IT Director, Male)

He went on to say:

'When he (then CEO) ran town-hall meetings across the business, when he explained "look, this is how our profits are going down year on year" and extrapolated that in one to two years we will be making a loss, it was an extremely simple line graph which people saw over and over again until it was ingrained in their minds that the airline is going to be in serious trouble.' (P3, Former IT Director, Male)

The then CEOs ability to involve employees was expressed by another respondent when he recalled:

'I still remember vividly Titus standing up there and asking: "Which one of these three options should we go for?" It was a vote from the Senior Executives that we should go for the aggressive option, which was to grow to 150 destinations. Just like any team, we had a set of ambitious leaders who were confident that we were going to deliver on the strategy.' (P2, Former Strategy Director, Male)

It is clear that the then CEO favoured a consultative management style and liked to involve KQ employees in the search for solutions to the airline's problems. This made him very popular with employees and was successful during the good days when the airline was profitable. However, during the turnaround process, his style ran contrary to the recommendations of the turnaround literature, namely that a CEO should personally drive a turnaround and take full responsibility for it (Bibeault 1999; Hofer 1980). Hofer (1980) contended that the type of turnaround leader required depends on the kind of turnaround strategy adopted. In the case of a high-growth turnaround like KQ's Project Mawingu, an entrepreneurial CEO was recommended, but 'a hardnosed, experienced cost-cutter' would have been ideal for an operating turnaround which involved major cost cutting, as KQ's KATAP and Operation Pride did. The then CEOs approach suited neither strategy, although it was ideal for the KATAP.

\section{Theme 2: Exogenous factors}

Project Mawingu, which was launched a year after EAL's Vision 2025, and it was meant to be a major turning point in KQ's fortunes. Although it turned out to be disastrous for $K Q$, interview participants were unshakeable in their conviction that Project Mawingu would have been successful, but for a number of damaging exogenous factors. This was another key theme which emerged from the data collected for the study. One of the participant explained it as follows:

'We had the Mawingu strategy, which we set out to execute, which was a growth strategy. There were shocks along the journey, and we were not able to withstand them, for good or bad reasons. There were certain events: the airport burnt in August during peak season, the peak of peaks. When the airport burns during peak, many of the people who were booked think 'actually, there is no airport'. There was an Ebola attack in West Africa, and we ended up stopping to operate to Freetown and Monrovia. The airline lost $\$ 50 \mathrm{~m}$. There was the Watergate [terrorist] attack. There was the Mpeketoni [terrorist] attack. So, there were a series of events.' (P2, Former Strategy Director, Male)

A former Communications Manager said that the Operation Mawingu plan that she saw upon joining the airline in 2015 was 'actually a good project'. However, 'Murphy's Law happened: anything and everything that could go wrong, went wrong'. This is how she explained it:

'In the early years of 2010, 2011 and 2012, we had a lot of terroZrism in Kenya. We had continued attacks almost all the years up to 2015; there were a lot of attacks in terms of terrorism. For many years, KQ basically survived on tourism, and when the number of tourists dropped, that drastically affected KQ. Another thing that really affected $\mathrm{KQ}$ was Ebola because West Africa was going to be a money maker for $K Q$, and when we didn't fly to West Africa for almost 8 months, our revenues were affected.' (P5, Former Communications Manager, Female)

Although there is not much that can be done about exogenous factors, nevertheless Kourdi (2009:33) and Reeves et al. (2015) emphasised the need for a company to ensure that, as far as possible, its strategy takes present and future trends into account and is sufficiently flexible to cope with unexpected circumstances.

Kourdi (2009) argued that successful strategies are flexible and recommended that companies should strive for a balance 
between placing too heavy an emphasis on either the past or the future. Reeves et al. (2015) contended that given the dynamism of today's business environment, it is important that business leaders continuously assess the environments in which their companies operate and then adapt their strategies appropriately. They state that the fast pace of change increases the chances of a company's strategy being badly matched to the environment, a situation which leads to companies' life cycles being significantly reduced or even halved. Consequently, the most potent weapon in a business's arsenal is the ability to respond promptly to signals that a company is in a harsh environment.

\section{Theme 3: High operational and debt-servicing costs}

Project Mawingu left KQ heavily indebted. Just over half the amount (US\$14b, instead of US\$22b) that was expected to be raised through a rights issue was realised, leaving a shortfall of $\$ 8 \mathrm{~b}$. The former Strategy Director said that it was hoped that the shortfall would be financed from operations, but KQ was 'not even making an operating profit' at the time, thanks to the aforementioned exogenous shocks in the market. That forced KQ to 'go to the banks to borrow money to finance both [aircraft] pre-delivery payments and the operations' (P2, Former Strategy Director, Male).

A former CEO described Operation Pride as an operational and financial turnaround:

\begin{abstract}
'Operationally, the biggest things were really around how we renegotiate the different things we have. There were some big things to renegotiate. How do you renegotiate lease contracts? How do you renegotiate financing arrangements because it's part of the cash flow? How do you renegotiate supply contracts? How do you renegotiate on terms, for example, the main cost around the crew? What is the external environment around restructuring? Because you are operating in Africa, the environment could be misconstrued if you are taking action that may have certain implications, so a lot of stakeholder engagements were needed in terms of that.' (P1, Former Chief Executive Officer, Male)
\end{abstract}

The former Strategy Director said that as they tried to generate revenue to service debt and to reduce the quantum of losses, uppermost in their minds was the need to maintain the airline's licence to operate:

\footnotetext{
'The strategy was about going back to profitability because the airline had been losing money, at least at operating level. The other thing was about regaining our licence to operate because in an airline if you start making losses, the regulators and other people start getting worried and your licence to operate can easily be compromised. The third thing is that we were actually operating the business for cash. At that time, we were bleeding.' (P2, Former Strategy Director, Male)
}

The former CEO's decision to attend to debt restructuring is consistent with the views of most turnaround scholars. Bibeault (1999) posited that lender and creditor support for bridge financing during a turnaround is critically important. He equated money to blood transfusion for a very ill patient, arguing that 'cash is the lifeblood of the business'. Gadiesh, Pace and Rogers (2003) and Gotteiner et al. (2019) stated that shoring up a company's balance sheet and cash position should be one of the first things done during the emergency stage of a corporate turnaround. Gotteiner et al. (2019) listed financial restructuring, working capital improvements and operation revenue generation as being amongst the most urgent and prudent things to do during a turnaround.

\section{Theme 4: Management-Union friction}

Friction between management and labour at KQ was another theme which emerged in the course of the data analysis. In particular, the Kenya Airline Pilots Association (KALPA) and the Kenya Aviation Workers Union led the attack on the carrier's leadership, which forced the resignation of two CEOs, first Naikuni and later Mbuvi Ngunze.

In January 2016, following a loss of KSh25.7b for the year ending in March 2015, KALPA Secretary-General, Captain Paul Gichinga, called for the KQ leadership's resignation (Karambu 2016). Gichinga said in his statement:

'KALPA has over the years questioned the airline's business strategy and deteriorating employee relations. Following KQ's dismal performance in the financial year ended March 2015, and ongoing attempts at a turnaround, it is our position that Kenya Airways' recovery cannot be left in the hands of those who oversaw its downward spiral.' (KALPA Secretary-General, Paul Gichinga, Male)

The former Marketing Director said that KQ pilots had demanded salary increase at a time when the airline was suffering growing losses:

'One thing is that the airline was trying to reduce costs, and at the same time, $80 \%$ of the salary bill is spent on pilots. Pilots were asking for salary increments. There were a lot of union issues. The organisation has a very strong union, so you find that the relationship between the management and the pilots was a bit frosty. In the end, the pilots wanted to strike if the chairman and the CEO were not removed. Those types of issues affect the business because pilots would embark on a go-slow strike, which means that they would come to work, but they would delay the aircraft from taking off or they would call off sick at the last minute.' (P4, Former Marketing Director, Female)

The fractious nature of the relationship between the airline and organised labour saw the TMT's attention divided between managing a turnaround and handling labour issues. However, trade unions in the aviation industry have been increasingly more aggressive as the industry experience change in many countries and trade unions seek to protect precarious jobs (Broughton 2005). Chattopadhyay (2015) pointed out that labour has considerable bargaining power because 'airlines use capital-intensive equipment that is useless unless flown'. This bargaining power has enabled unions to negotiate 'generous pay packages and exceptionally good working conditions for employees', leading to workers' contracts being very complex and generous to labour (Chattopadhyay 2015). 


\section{Theme 5: Debt restructuring}

Although Kenyan banks were initially vehemently opposed to the conversion of their loans from KQ into equity, they eventually agreed to the deal when the Kenyan government offered them guarantees for their loans. Collectively, the local banks owned $39 \%$ of the airline through a special purpose vehicle called KQLenders Company, with KLM's shareholding reduced to 7.95\% (MarketScreener 2020). Aglionby (2017) said the following about the restructuring:

The government will convert some of its $\$ 237 \mathrm{~m}$ of debt into $19.1 \%$ of the airline, which is mired in negative equity and is some $\$ 2 \mathrm{~b}$ in debt. Its stake in Kenya Airways before the restructuring was $29.8 \%$. A zero-coupon convertible loan agreement has been agreed upon to cover the remainder of the debt. The banks, which previously did not own any of the airline, will convert $\$ 167.2 \mathrm{~m}$ of their $\$ 217.24 \mathrm{~m}$ debts into $38.1 \%$ of the company, to be held by a newly formed company called the KQ Lenders Company. They have also entered into a convertible loan agreement to cover the remaining $\$ 50 \mathrm{~m}$ of the debt, although the coupon rate is yet to be disclosed. Neither the government nor the banks intend to make a takeover offer for Kenya Airways. Both have applied to the Kenyan Capital Markets Authority for an exemption from having to make a bid.

This is what the former CEO said in an interview with this researcher in 2019:

'Even though I left as the CEO, the Board asked me to stay on to complete the financial restructuring, which was just a mark of confidence of what they saw around the financial restructuring because they felt I was the only one who could deliver the financial restructuring. So, they asked me to stay on as a Board Advisor until we finish the financial restructuring. By the time I left, the operational part was gaining a lot of traction because most of the big wins that we put in place, such as negotiations with aircraft lessors, were successful. We sold the aircraft we wanted to sell. Sub-leasing of assets took out $\$ 280 \mathrm{~m}$ worth of cost in terms of aircraft costs.' (P1, Former Chief Executive Officer, Male)

The decision to embark on a restructuring of KQ's debts is consistent with the advice in the turnaround literature. Bibeault (1999) stated that 'creditor pressure' is one of the challenges, which often confronts a company implementing a turnaround strategy; hence bridge capital is vital to finance a turnaround. Bibeault (1999) argued that lender support for bridge finance is so crucial that without it, 'a company's viability is in serious doubt'. The literature is clear that a turnaround strategy cannot be implemented successfully without an access to adequate capital (Bibeault 1999; Gadiesh et al. 2003; Onich 2020). Bibeault (1999) argued that during a turnaround, 'more than at any other time in the corporate life span, "cash is king"'.

\section{Theme 6: Nationalisation}

When Operation Pride was embarked upon in 2015, the intention was to turn KQ around and ensure that it returned to profitability as a private, listed company. Neither Operation Pride nor the COP was intended to prepare the airline for nationalisation (Kamau 2017). However, in July 2019, the Kenyan Parliament voted to nationalise $\mathrm{KQ}$ 'to save it from mounting debts'. This followed the Transport Committee's rejection of the then $\mathrm{CEO}$ for $\mathrm{KQ}$ to take over the running of JKIA (which has annual revenues of KSh12b, half of which is profit) 'to boost its revenue' (Reuters 2019) and its subsequent recommendation - which was debated by the Kenyan Parliament on 18 June 2019 - for the airline's nationalisation (Reuters 2019).

KQ's nationalisation did not meet with universal approval. Amongst the people who disapproved was a KQ minority shareholder:

'There is not a very good record of airlines being well-run by the state. You have issues where ministers appoint home boys and home girls to the boards. There used to be a thing in the 1980s where the airline had two Airbus aircrafts, very nice planes, and the president would take them for a trip. If he was going to London, one of the aircrafts would become the presidential plane. A plane probably has four destinations a day. When you take it out of service like that, what would happen? People would be upgraded out of nowhere, without having to pay. You hope that won't be the case.' (P6, Shareholder representative, Male)

The former Communications Manager expressed the hope that if the airline were nationalised, that would be for a short period, after which it would again be privatised:

'Sometimes, when you have reached rock bottom, you might have to go back home to start your journey. It probably would not be nationalisation for a very long time, but they [KQ] need to get their act together before they can be re-privatised. Probably, reprivatisation will require a different skill set because there is also a belief that when it was privatised, KQ got a raw deal from KLM. It has always been hamstrung by the fact that the agreement was not favourable to KQ. If anything, it killed the airline. They should probably nationalise it for a period of 5 years. It should not become like a government department, but it should have the government as a big brother and be run professionally, turn its fortunes around and then look for an investor, probably another airline.' (P5, Former Communications Manager, Female)

The decision by the Kenyan Government to nationalise KQ goes against the global trend, which has seen formerly stateowned airlines either being fully privatised or selling equity to private airlines or companies. In a study conducted in 2004 for the Government of Ireland, Goldman Sachs found that of 18 European countries examined, only five - Malta, Czech Republic, Hungary, Greece and Portugal - still retained 100\% state ownership of the national airlines at that time (Barrett 2006). In conclusion, Goldman Sachs (2004) stated that 'most governments' no longer considered public ownership of airlines to be 'an important element of public policy and use other means to achieve their objectives as airline stakeholders'.

Button (2003:6) stated that many airline markets had been transformed from regulated monopolies to 'more free market-based structures', with the proportion of the world's largest 25 airlines - which accounted for about $62 \%$ of total capacity - that were previously owned by governments having decreased from $38 \%$ to $10 \%$. Viewed against the background of the same conceptual framework, the findings indicate that $\mathrm{KQ}$ was likely to be successful in the implementation of its turnaround strategy, as shown in Figure 1. However, the airline was partly successful in the 


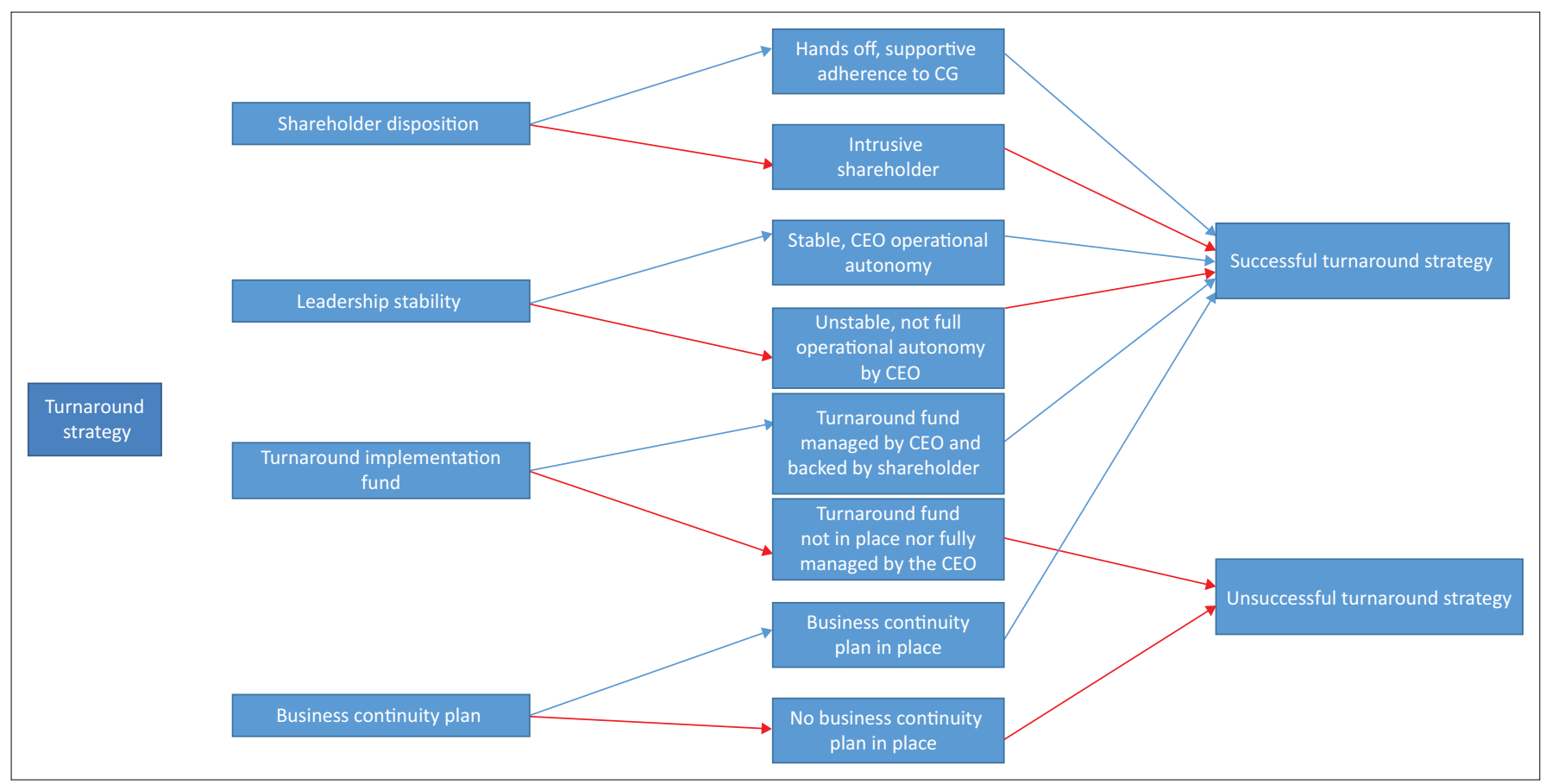

CEO, Chief executive officer; CG, Corporate governance.

FIGURE 1: Implementation framework for turnaround strategies at Kenya Airways.

implementation of its turnaround strategies as it managed to reduce costs considerably and to generate sufficient revenue to be operationally profitable.

\section{Theme 7: Leadership}

The kind and quality of leadership which KQ has had since 2003 was another theme which emerged from the analysis of the primary data gathered through the interviews.

An Ethiopian-based aviation journalist said that the media found Naikuni inaccessible:

'I met him many times at aviation conferences, including in Mombasa when Kenya Airways hosted the AFRAA [African Airlines Association] AGM. Not once did he grant me an interview. That tells you something. I interviewed his successor, Mbuvi Ngunze, and even Sebastian Mikosz. I interviewed Mikosz 4 days after he took office, but I never got a chance to interview Naikuni. I spoke to Kenyan journalists, and they told me that they had had the same experience with him.' (P9, Ethiopian aviation journalist, Male)

The former Communications Manager, who worked very closely with Ngunze on Operation Pride and the COS, was very complimentary about his leadership:

'By the time, the former CEO was leaving, we wished we could clone him. What he was doing was very important. It took all his time, but then he also needed to run the business with the historical background of what had happened.' (P5, Former Communications Manager, Female)

The manager however, was not as appreciative about Mikosz, who was employed as an external turnaround leader from Poland and with whom she had worked for 5 months. She said although he tried his best, he did not come across as being sufficiently passionate about $\mathrm{KQ}$ and did not make much effort to understand his Kenyan colleagues:

'I do not think that he knew what to expect when he came to Africa, and it was very clear. He wasn't necessarily very open. His management style was also very different, and he came at a time when KQ had had these two CEOs who are Kenyans, who are Africans, so they understood the nuances. I don't know if he actually got there, but I know it took him quite a while just even to understand the cultural nuances.' (P5, Former Communications Manager, Female)

'To be very honest, Kenyans are very passive-aggressive. It's a thing for Kenyans. I tried to coach him, to tell him 'this is how Kenyans react; you have to be very careful'. I don't think he has succeeded. I think he came with an expectation of how he would do this and did not expect the kind of push-back that he has received, and he had to contend with it both internally and externally.' (P5, Former Communications Manager, Female)

The former IT Director said that Mikosz had achieved 'very minimal success' at KQ, and said that the return to the airline of aircraft which had been sub-leased for a 3-year period would add extra capacity, 'without markets to take the aircraft into':

'I see a very difficult time for the airline again, until it gets what I would call the right leadership with pragmatism, being realistic but involving and getting everybody committed to rallying behind the right cause. Right now, judging by the kind of noise we hear from the airline, it's rather obvious that they are not on the same page.' (P3, Former IT Director, Male)

The KQ Public Relations (PR) consultant also expressed the view that Mikosz had not succeeded as the CEO. She argued that KQ needed 'the right leadership' to improve its chances of being turned around:

'They need new leadership that is committed to the turnaround. Mbuvi [Ngunze] was. If you read the papers back when he was 
the CEO or saw him speak at functions, he was committed to the cause. We know that leadership can change a lot of things. The right leadership will get things in place. They need to grow, but not be overly ambitious, and probably even exit some of their current routes, as long as there is a proper growth strategy around it.' (P11, Kenyan Airways Relations Consultant, Male)

Given that $\mathrm{KQ}$ was heavily indebted and was making growing losses and that the initial cause of its decline was internal (even though it was compounded by exogenous factors), the appointment of Sebastian Mikosz, an outsider who had achieved success at Polskie Linie Lotnicze (Polish Airlines), as the turnaround leader was consistent with the dominant view in the literature on turnaround strategies. Hofer (1980) considered the change of a company's TMT to be 'a precondition for almost all successful turnarounds'.

Such appointments improve the chances of the new CEO correctly and dispassionately diagnosing the cause of a company's decline and developing appropriate strategies to stem the decline and return the company to profitability (Arogyaswamy et al. 1995; Bibeault 1999; Dimopoulos \& Wagner 2016; Gadiesh et al. 2003; Gotteiner et al. 2019; Hofer 1980; Schoenberg et al. 2013; Walshe et al. 2010).

Leadership stability and appropriate management skills are an absolute necessity for the successful implementation of a turnaround strategy, and that the CEO must own the strategy and enjoy the support of the BoD and the shareholders. Whilst the existence of a BoD which observes the prescripts of good corporate governance reduces the chances of an agent-principal problem, a situation where the shareholder is dominant and has the final say in decision-making, in the process dictating to both the $\mathrm{BoD}$ and the TMT, gives rise to a different kind of challenge, namely an anxious principalagent problem, which was not anticipated by Ross's (1973) and Jensen and Meckling's (1976) agency theory.

In light of the foregoing, the study posits the following framework for future implementation of turnaround strategy that KQ may employ. Many state-owned enterprises may also find the framework useful for their turnaround strategies implementation.

The framework shows the paths that the Kenya Airways should take that will lead to the implementation of a successful turnaround strategy. The framework also shows paths that would result in the unsuccessful turnaround strategy implementation. The primary data and the literature show that shareholder disposition, leadership stability, turnaround implementation fund and the business continuity plan in the case of disruptive events are all key ingredients of a successful turnaround strategy.

\section{Conclusion}

The aim of this study was to explore experiences and challenges associated with the Kenya Airways implementation of its turnaround strategies. The findings presented above indicate the following challenges, which have resulted in failure by KQ to implement its turnaround strategies. First, KQ was traditionally very consultative in the formulation of its turnaround strategies and involved its employees in the identification of appropriate revenue-generation and costcontainment initiatives. Whilst employee consultation has its merits during a period of stability, this high level of employee involvement meant that the CEO did not exercise the authority recommended in the literature during a turnaround. Second, a series of exogenous factors - such as terrorist attacks in Kenya, the outbreak of the Ebola Virus epidemic in West Africa and fire at JKIA in Nairobi - seriously affected KQ financially. These events scared off tourists and business travellers from Kenya and led to $\mathrm{KQ}$ cancelling its flights to popular destinations like Monrovia in Liberia and Lagos in Nigeria. Third, following huge costs incurred to purchase aircrafts as part of KQ's growth strategy, Project Mawingu, the airline which was unable to realise the forecast revenues - was left with high operational and debt-servicing costs. As a result, it has recorded a series of losses since 2015, from which it is yet to recover. This necessitated its operational turnaround strategy, Operation Pride.

Fourth, the growing friction between the KQ TMT and labour, in particular the KAPA, meant that the airline did not have the support of a crucial internal stakeholder at a critical time when it needed all employees to pull in the same direction. This had a disruptive effect on the airline. Fifth, following the airline's inability to service its debts, KQ found itself forced to embark on debt restructuring, through its Cost Optimisation Plan (COP). This led to a situation where the Kenyan Government ended up being the single largest shareholder. Sixth, as a result of its high indebtedness and the debt restructuring mentioned above, and following the rejection of KQ's proposal for the airline to be allowed to run the JKIA, the Kenyan Parliament voted to nationalise the flag carrier, thus rendering its future uncertain. Finally, the role played by KQ's CEOs in the past two decades was another important theme that emerged from the data analysis. The leadership of Titus Naikuni and Mbuvi Ngunze was more appropriate for a time of corporate stability. Although Sebastian Mikosz adopted the appropriate approach to leadership as a turnaround leader, he found it difficult to settle in at $K Q$ in terms of organisational culture and ended up alienated from both the airline's employees and key stakeholders in the Kenyan Government.

This study makes a meaningful contribution to the body of knowledge on the implementation of turnaround strategies at SOEs. This study contributes to the body of knowledge on turnaround strategies, especially in the context of African businesses (one of which is state-owned and the other privately owned) and improves the chances of the successful implementation of turnaround strategies in African airlines by practitioners. In particular, it establishes what determinants contribute towards or detract from the successful implementation of a turnaround strategy. 
In addition to contributing to the body of knowledge on turnaround strategies, this study should also be helpful to African researchers and practitioners on strategy in general and turnaround strategies in particular. Managerially, this study has provided a framework which points toward the paths that lead to the successful and unsuccessful implementation of the turnaround strategy. Furthermore, whilst it is important to take into account the needs of employees and union, turnaround strategies are not times for extensive consultation but of decisive leadership on the part of the CEO. It is thus imperative for governments as shareholders in the airline companies to support and take a hands-off approach when it comes to the day-to-day running of the business, and leave that entirely in the hands of the appointed CEO. As a key stakeholder, governments should ensure that the CEO is provided with adequate capital for operational revenue growth and working capital improvement. The study has also highlighted the need for appropriate skills set on the part of the TMT owing to the complexity of the airline business and turnaround strategies implementation.

Notwithstanding the study's contribution to the study of turnaround strategies and to practice, it is without limitations. Whilst the study sought to elicit responses from participants with the deep knowledge of the KQ airlines, it did not consider whether lessons from previous turnarounds flowed into the next ones. Because employees at junior levels generally outstay senior members of management, study did not include their perspectives and insights on the turnaround strategies. Thus, for future research, studies can determine whether any lessons learned from previous turnaround strategies have a bearing on how the current ones are being managed. Future studies may also take a quantitative analysis approach where the perceptions of all employees can be taken into account.

\section{Acknowledgements Competing interests}

The authors declare that they have no financial or personal relationships that may have inappropriately influenced them in writing this article.

\section{Authors' contributions}

K.N. was a PhD student and this article is based on his work. D.P. was the supervisor of the $\mathrm{PhD}$ project and edited the manuscript.

\section{Ethical considerations}

This article followed all ethical standards for research without direct contact with human or animal subjects.

\section{Funding information}

This research received no specific grant from any funding agency in the public, commercial or not-for-profit sectors.

\section{Data availability}

Data are available upon reasonable request from the first author.

\section{Disclaimer}

The views and opinions expressed in this article are those of the authors and do not necessarily reflect the official policy or position of any affiliated agency of the authors, and the publisher.

\section{References}

Aglionby, J., 2017, Kenya Airways agrees debt-for-equity restructuring terms, Financial Times, viewed 11 October 2019, from https://www.ft.com/content/9fad4091b1be-3098-b510-6d658c113371/.

Amollo, B.A., 2015, Mawingu project quality and risk management, viewed 14 September 2020 , from https://www.academia.edu/27407935/mawingu project quality and risk management.

Arogyaswamy, K., Barker, V.L. \& Yasai-Ardekani, M., 1995, 'Firm turnarounds: An integrated two-stage model', Journal of Management Studies 32(4), 493-525. https://doi.org/10.1111/j.1467-6486.1995.tb00786.x

Ayiecha, F.O.O. \& Katuse, A., 2014, 'Implementing turnaround strategy: Effect of change management and management competence factors', IOSR Journal of Business and Management 16(3), 95-103. https://doi.org/10.9790/487X-163595103

Barrett, S.D., 2006, 'Commercialising a national airline - The Aer Lingus case study', Journal of Air Traffic Management 12, 159-167. https://doi.org/10.1016/j. jairtraman.2005.11.001

Baxter, P. \& Jack, S., 2008, 'Qualitative case study methodology: Study design and implementation for novice researchers', The Qualitative Report 13(4), 544-559.

Bhattacherjee, A., 2012, Social science research: Principles, methods and practices, Scholar Commons, University of Florida, FL.

Bibeault, D.B., 1999, Corporate turnaround: How managers turn losers into winners!, Beard Books, Washington, DC.

Brinson, L., 2002, Kenya Airways Expands its All-Boeing Fleet With 777s, Boeing, viewed 28 January 2021, from https://boeing.mediaroom.com/2002-03-18Kenya-Airways-Expands-its-All-Boeing-Fleet-with-777s,1.

Broughton, A., 2005, Industrial relations in the airline sector, viewed 14 February 2021, from https://www.eurofound.europa.eu/publications/report/2005/ industrial-relations-in-the-airline-sector.

Bryman, A. \& Bell, E., 2014, Research methodology, Oxford, Cape Town

Button, K., 2003, 'Does the theory of the "core" explain why airlines fail to cover their long-run costs of capital?', Journal of Air Transport Management 9(1), 5-14. https://doi.org/10.1016/S0969-6997(02)00075-3

Carlile, P.R. \& Christensen, C.M., 2005, The cycles of theory building in management research, Working Paper (Volume 5), Boston University, Boston.

Chattopadhyay, C., 2015, 'Aviation industry: Challenges and prospects', Journal of Research in Business, Economics and Management 3(2), 145-149.

Cooper, D.R. \& Schindler, P.S., 2014, Business research methods, 12th edn., McGrawHill, New York, NY.

Debrah, Y. \& Toroitich, O.K., 2005, 'The Making of an African Success Story: The Privatization of Kenya Airways', Thunderbird International Business Review 47(2), 205-212.

Dimopoulos, T. \& Wagner, H.F., 2016, Corporate Governance and CEO Turnover Decisions, Swiss Finance Institute Research Paper No. 12-16, viewed 08 April 2017, from http://ssm-com/abstract=2040690.

Doganis, R., 2019, Flying off course: Airline economics and marketing, 5th edn., Routledge Taylor and Francis Group, London.

Gadiesh, O., Pace, S. \& Rogers, P., 2003, 'The strategic leader. Successful turnarounds: Three key dimensions', Strategy \& Leadership 21(6), 41-43. https://doi org/10.1108/sl.2003.26131fab.001

Ghazzawi, I.A., 2018, 'Organizational turnaround: A conceptual framework and research agenda', American Journal of Management 17(7), 10-24. https://doi. org/10.33423/ajm.v17i7.1698

Goldman Sachs International, 2004, Evaluation of ownership options regarding Aer Lingus p/c, Government Publications, Dublin.

Gotteiner, S., Mas-Mashuca, M. \& Marimon, F., 2019, 'Turnaround types, stages, strategies and tactics: Putting things in order', European Accounting and Management Review 5(2), 12-37. https://doi.org/10.26595/eamr.2014.5.2.2

Hennink, M.M., Kaiser, B.N. \& Marconi, V.C., 2016, 'Code saturation versus meaning saturation: How many interviews are enough?', Sage Publications 27(4), 591-608. https://doi.org/10.1177/1049732316665344

Heshmati, A. \& Kim, J., 2016, Introduction to efficiency and competitiveness of International Airlines, pp. 1-14, Efficiency and competitiveness of International Airlines, Springer Science \& Business Media, New York.

Hofer, C.W., 1980, 'Turnaround strategies', Journal of Business Strategy 1(1), 19-31 https://doi.org/10.1108/eb038886

Jensen, M.C. \& Meckling, W.H., 1976, 'Theory of the firm: Managerial behavior, agency costs and ownership structure', Journal of Financial Economics 3(4), 305-360.

Jin, X., Qu, M. \& Bao J., 2019, 'Impact of crisis events on Chinese outbound tourist flow: A framework for post-events growth', Tourism Management 74, 334-344. https://doi.org/10.1016/j.tourman.2019.04.011 
Kalwani, V., 2012, An in-depth look at corporate turnarounds from the lens of organizational learning, viewed 18 August 2018, from https://www.
semanticscholar.org/paper/AN-IN-DEPTH-LOOK-AT-CORPORATE-TURNAROUNDSFROM-THE-Kalwani-Ivey/ba77be78d2087f3a0c447094994495b31c8aad76.

Kamau, M., 2017, Intrigues behind Kenya Airways debt restructuring: The Standard, viewed 24 May 2019, from https://www.standardmedia.co.ke/business-news/ article/2001261938/intrigues-behind-kenya-airways-debt-restructuring.

Karambu, I., 2016, 'Disband Kenya Airways management, pilots demand', Nation, viewed 07 October 2017, from https://nation.africa/kenya/business/disband-kenya-airwaysmanagement-pilots-demand-1162796.

Kenya Airways, 2017, 40 Years of Pride: Annual Report \& Financial Statements, viewed 23 September 2020, from https://www.kenya-airways.com/uploadedFiles/ Content/About_Us/Investor_Information/Book\%20KQ\%2010996\%20Annual\%20 Report_Website.pdf.

Kourdi, J., 2009, Business strategy: A guide to taking your business forward, 2nd edn., Profile Books, London.

Marczyk, G., DeMatteo, D. \& Fesinger, D., 2005, Essentials of research design and methodology, Wiley, Hoboken, NJ.

MarketScreener, 2020, Kenya Airways PLC (KQ), viewed 04 March 2021, from https://www.marketscreener.com/KENYA-AIRWAYS-PLC-6493924/company/.

Mburu, E.W., 2016, 'Challenges of implementation of turnaround strategies and performance of postal corporation of Kenya', a research project submitted in partial fulfillment of the requirement for the award of the degree of Master of Business Administration, School of Business, University of Nairobi.

Mcmillan, J.H. \& Schumacher, S., 2010, Research in education: Evidence-based inquiry, Pearson, Boston, MA.

Munaita, P., 2015, 'Project Mawingu' strategists had their heads in the clouds, viewed 15 June 2019, from https://www.theeastafrican.co.ke/tea/news/east-africa/project-mawingu-strategists-had-their-heads-in-the-clouds--1338858.

Nduta, N.A. \& Deya, J., 2020, 'Influence of turnaround strategies on performance of firms in the aviation industry in Kenya', International Journal of Academic Research in Accounting, Finance and Management Sciences 10(3), 135-149. https://doi. org/10.6007/IJARAFMS/v10-i3/7705

Neilson, G.L., Martin, K.L. \& Powers, E., 2008, The secrets of successful strategy execution HBR's 10 must reads on strategy, Harvard Business School Press, Boston, MA.

Nowell, L.S., Norris, J.M., White, D.E. \& Moules, N.J., 2017, 'Thematic analysis: Striving to meet the trustworthiness criteria', International Journal of Qualitative Methods 16, 1-13. https://doi.org/10.1177/1609406917733847

O'Kane, C. \& Cunningham, J., 2014, 'Turnaround leadership core tensions during the company turnaround process', European Management Journal 32(6), 963-980. https://doi.org/10.1016/j.emj.2014.04.004

Onich, T., 2020, The turnaround - Elements of success: TCMI Management consulting for corporate renewal, viewed 10 May 2021, from http://www. turnaroundinternational.com/TheTurnaround.pdf.

Oqubay, A. \& Tesfachew, T., 2019, 'How they did it: Getting granular in solving policy issues', The Journey of Ethiopian Airlines 2(1), 1-16, viewed 02 March 2020, from https://www.afdb.org/en/documents/document/policy-brief-how-they-did-itvol-2-issue-1-the-journey-of-ethiopian-airlines-107363.
Panicker, S. \& Manimala, M.J., 2015, 'Successful turnarounds: The role of appropriate entrepreneurial strategies', Journal of Strategy and Management 8(1), 21-40. https://doi.org/10.1108/JSMA-06-2014-0050

Parrick, M., 2018, 11 Corporate Turnaround Success Stories, viewed 16 February 2020, from https://brownandjoseph.com/blog/11-turnaroundsuccess-stories.

Pretorius, M., 2009, 'Defining business decline, failure and turnaround: A content analysis', The Southern African Journal of Entrepreneurship and Small Business Management 2(1), 1-16. https://doi.org/10.4102/sajesbm.v2i1.15

Ravaghi, H., Mannion, R. \& Sajadi, H.S., 2017, 'Organizational failure and turnaround in public sector organizations: A systematic review of the evidence', Medical Journal of the Islam Republic of Iran 31(76), 1-11. https://doi.org/10.14196/mjiri.31.76

Reeves, M., Haanaes, K. \& Sinha, J., 2015, Your strategy needs a strategy: How to choose and execute the right approach, Harvard Business School Press, Boston, MA.

Reuters, 2019, Exclusive: Kenya Airways goes full circle with two-year nationalization plan, viewed 24 April 2020, from https://www.reuters.com/article/us-kenyaairways-restructuring-exclusive-idUSKCN1UK22M.

Rogers, P. \& Blenko, M., 2006, Who has the D? How clear decision roles enhance organizational performance: HBR's 10 must reads on strategy, Harvard Business School Press, Boston, MA.

Ross, S.A., 1973, 'The economic theory of agency: The principal's problem', American Economic Review 63(2), 134-139.

Rossello, J., Becken, S. \& Santana Gallego, M., 2020, 'The effects of natural disasters on international tourism: A global analysis', Tourism Management 79, 1-11. https://doi.org/10.1016/j.tourman.2020.104080

Rudestam, K.E. \& Newton, R.R., 2015, Surviving your dissertation: A comprehensive guide to content and process, 4th edn., Sage, Los Angeles, CA.

Schoenberg, R., Collier, N. \& Bowman, C., 2013, 'Strategies for business turnaround and recovery: A review and synthesis', European Business Review 25(3), 243-262. https://doi.org/10.1108/09555341311314799

Suarez, F.F. \& Lanzolla, G., 2007, 'The role of environmental dynamics in building a first mover advantage theory', The Academy of Management Review 32(2), 377-392. https://doi.org/10.5465/amr.2007.24349587

Thiong'o, N., 2012, Kenya Airways 10-year strategy, PowerPoint Presentation, viewed 09 March 2018, from http://www.slideshare.net/thiongonick/kenya-airways-10 year-strategy.

Trahms, C.A., Ndofor, H.A. \& Sirmon, D.G., 2013, 'Organizational decline and turnaround: A review and agenda for future research', Journal of Management 39(5), 1277-1307. https://doi.org/10.1177/0149206312471390

Walshe, K., Harvey, G., Hyde, P. \& Pandit, N., 2010, 'Organizational failure and turnaround: Lessons for public services from the for-profit sector', Public Money \& Management 24(4), 201-208. https://doi.org/10.1111/j.1467-9302.2004.00421.x

Wolla, S.A. \& Backus, C., 2018, The economics of flying: How competitive are the friendly skies?, Federal Reserve Bank of St. Louis, viewed 13 May 2019, from https://research.stlouisfed.org/publications/page1-econ/2018/11/01/theeconomics-of-flying-how-competitive-are-the-friendly-skies/.

Yin, R.K., 2014, Case study research - Design and methods, 5th edn., Sage, Los Angeles, CA. 